\title{
Methylation Status of CYP27B1 and IGF2 Correlate to BMI SDS in Children with Obesity
}

\author{
Orsolya Ács $^{a} \quad$ Bálint Péterfia $^{b}$ Péter Hollósib, ${ }^{b}$ Andrea Luczay ${ }^{d}$ \\ Dóra Török ${ }^{a}$ András Szabóa \\ a 2nd Department of Pediatrics, Semmelweis University, Budapest, Hungary; ${ }^{\text {b}} 1$ st \\ Department of Pathology and Experimental Cancer Research, Semmelweis University, \\ Budapest, Hungary; ${ }^{\top}$ Tumor Progression Research Group, Hungarian Academy of Sciences, \\ Budapest, Hungary; ${ }^{\text {d}} 1$ st Department of Pediatrics, Semmelweis University, Budapest, \\ Hungary
}

\section{Keywords}

DNA methylation $\cdot$ Childhood obesity $\cdot$ Insulin-like growth factor $2 \cdot$ Vitamin $D$

\begin{abstract}
Objective: Worldwide increasing childhood obesity is due to interactions between environmental and genetic factors, linked together by epigenetic mechanisms such as DNA methylation. Methods: 82 obese children (>95th BMI percentile, age: 3-18 years) were included. Anthropometric data, metabolic parameters, $25-\mathrm{OH}$ vitamin $\mathrm{D}(25 \mathrm{OHD})$, and pubertal status were recorded, 24-hour blood pressure monitoring was performed. BMI standard deviation score (SDS) was calculated. Using candidate gene approach, obesity- (insulin-like growth factor 2 (IGF2), proopiomelanocortin $(P O M C)$ ) and vitamin D metabolism-related genes (1-alfahydroxylase (CYP27B1), VDR) regulated by DNA methylation were selected. After isolating DNA from peripheral blood, bisulfite conversion, bisulfite specific polymerase chain reaction (BS-PCR), and pyrosequencing were carried out. Results: No significant correlation between 25-OHD and metabolic parameters and DNA methylation status, but a tendency of positive correlation between VDR methylation status and 25-OHD $(r=0.2053, p=0.066)$ were observed. Significant positive correlations between BMI SDS and CYP27B1 hypermethylation $(r=0.2371, p=0.0342)$ and a significant negative correlation between IGF2 hypomethylation and BMI SDS ( $r=-0.305, p=0.0059)$ were found. Conclusions Rate of obesity shows correlation with DNA methylation. Hypomethylation of IGF2 and hypermethylation of CYP27B1 genes might positively influence the rate of BMI observed in obese children.
\end{abstract}


Ács et al.: Methylation Status of CYP27B1 and IGF2 Correlate to BMI SDS in Children with Obesity

\section{Introduction}

The prevalence of obesity has been increasing dramatically over the past years not only worldwide but in European countries as well. This condition tends to appear at younger ages, which indicates that the risk factors, comorbidities, and consequences of obesity start getting in action very early on in life [1]. The increase of body weight is also correlated with an increased risk of type 2 diabetes, cardiovascular diseases, cancer, and mortality [2]. The cause of obesity is complex and includes endogenous and exogenous factors. Researchers suggest that the main exogenous factor of the worldwide increasing weight gain is the 'obesogenic environment', which includes unfavorable changes in lifestyle and environment. At the level of individuals obesity is present when energy intake exceeds energy expenditure. But also endogenous factors can play a role in developing obesity. According to genomewide association studies (GWAS) more than 40 genetic variants have been associated with obesity and shifting in fat distribution, while gene-environment interaction is also proposed to be an important factor for causing obesity.

According to recent studies, obesity results mainly from interactions between environmental and genetic factors, which are linked together by epigenetic mechanisms $[3,4]$. The so-called epigenetic marking or 'imprinting' affects gene function and expression without modifying the DNA sequence. Epigenetic marks are tissue-specific and include DNA methylation, histone modification and micro RNA pathways, and influence cell function as well as molecular and metabolic processes [3]. Some nutritional components are able to influence the expression of some of the key genes in obesity via epigenetic changes. DNA methylation is the most studied epigenetic control mechanism that results in alteration of gene functions [5]. In utero obesity-linked epigenetic modifications also result from potential impact of the environment and influence the phenotype of the infant and continue to effect the development of obesity from infancy to adulthood [4]. Lately obesity studies that focus on epigenetic factors are not only based on 'obesogenic environment' but on candidate gene approach (CGA) too. According to CGA, expression of insulin-like growth factor 2 (IGF2) and proopiomelanocortin $(P O M C)$ genes correlate directly with growth, obesity, and body composition. IGF2 along with $H 19$ are imprinted genes controlling the regulation of growth and body composition. IGF2 triggers a major signal transduction pathway via activation of the IGF1 receptor, which mediates anabolic effects. Huang et al. [6] found that through increased DNA methylation of the IGF2/H19 region and therefore decreased expression of IGF2 leads to more subcutaneous fat mass in young adults. POMC gene, which encodes an anorexogenic neuropeptide, plays a central role in body-weight regulation within the hypothalamus through regulation satiety and energy expenditure. According to Marco et al. [8] in obesity the hypothalamic signal transduction pathway might be impaired, since high fat diet treated rats with obesity showed hyper methylated POMC promoter area. Kuehnen et al. [7] and Marco et al. [8] found that hypermethylation of the intron 2 and exon 3 boundary region of $P O M C$ gene is associated with childhood obesity.

The relationship between obesity and lower vitamin D levels has not been cleared yet. Vitamin D insufficiency and deficiency has become an issue worldwide. 25-hydroxy vitamin $\mathrm{D}$ (250HD) is the dominant circulating form of vitamin $\mathrm{D}$ and tends to be a useful indicator of the actual vitamin D status [9]. The activation and metabolism of 250HD is a complex process, which also includes the cytochrome P450 enzymes in the kidney and liver, e.g. the activating enzyme 1-alfa-hydroxylase (CYP27B1) in the kidney. The activity and the expression of the genes encoding these enzymes are also modulated by epigenetic pathways such as DNA methylation [10]. Vitamin D through its nuclear receptor (VDR) regulates epigenetic pathways and transcription of a number of genes involved in regulating metabolism and cell proliferation $[11,12]$. According to recent studies in adults, low levels of circulating $250 \mathrm{HD}$ are associated 
with increased fat mass, BMI, mortality, type 2 diabetes, cardiovascular diseases, and also dyslipidemia [13-18]. The expression of vitamin D metabolism-related genes and vitamin D receptor genes has been investigated in several studies focusing on cancer but rarely in patients with metabolic problems, especially in children suffering from obesity [19].

Therefore, the aim of our study was to investigate whether there is a correlation between the rate of obesity ( BMI and BMI standard deviation score (SDS)) and the methylation status of genes related to vitamin D metabolism (CYP27B1, VDR) and metabolic status (IGF2, POMC) in Hungarian children with obesity.

\section{Material and Methods}

\section{Subjects}

A total of 82 ( 40 boys and 42 girls) children were included in the study with age-and sex-specific BMIs above the 95th percentile, who were otherwise healthy and aged 3-18 years. Our probands were examined and followed up at the 2nd Department of Pediatrics, Semmelweis University, Budapest, Hungary.

\section{Anthropometric Data}

Anthropometric data (height, weight, waist circumference, birth height, and birth length), metabolic parameters (lipid profile, fasting blood sugar, insulin, data of oral glucose tolerance test, and thyroid stimulating hormone), vitamin D, serum calcium and parathormone levels as well as pubertal status were recorded, and a 24-hour blood pressure monitoring was carried out. BMI SDS was calculated in each case in order to estimate the relative degree of overweight. Patients' history was taken focusing on mother's weight gain during pregnancy, perinatal issues, development, eating habits, and lifestyle. We collected peripheral blood samples for DNA analysis from each patient.

The study was approved by the Semmelweis University Regional and Institutional Committee of Science and Research Ethics, and a written informed consent was provided in each case.

\section{DNA Isolation}

Genomic DNAs were extracted from peripheral whole blood using QIAamp DNA Blood Mini KIT (250) (Qiagen Inc., Valencia, CA, USA) according to the manufacturers' instructions.

\section{Quantitative Analysis of the Isolated DNA Samples}

Concentrations of isolated nucleic acid samples were measured with NanoDrop 1000 spectrophotometer (Thermo Fisher Scientific Inc., Waltham, MA, USA).

\section{Bisulfite Conversion}

Bisulfite conversion was performed using EZ DNA Methylation ${ }^{\mathrm{TM}}$ Kit (Zymo Research, Irvine, CA, USA) according to the manufacturer's instructions. Based on NanoDrop spectrophotometer measurements, quantity of input DNA isolated from peripheral blood was $1 \mu \mathrm{g}$. Bisulfite-converted DNA (bcDNA) samples were eluted in $10 \mu \mathrm{l}$ according to protocol. Concentrations of bcDNA samples were estimated by NanoDrop spectrophotometer using 'ssDNA' measurements.

\section{Bisulfite-Specific PCR}

In silico CpG island prediction of CYP27B1, VDR, IGF2 and POMC genes was performed by CpG Plot EMBOSS Application (www.ebi.ac.uk/Tools/emboss/cpgplot/index.html). For island prediction gene's start codon $\pm 5-10 \mathrm{~kb}$ region was used. In order to select best target regions ENCODE DNA methylation data was analyzed by the UCSC Genome Browser (https://genome.ucsc.edu; fig. 1). Bisulfite-specific PCR (BS-PCR) reactions were performed using primers designed with PyroMark Assay Design software (SW 2.0; Qiagen Inc.) to be specific for $\mathrm{CpG}$ regions in order to amplify the methylated sequence of the bcDNA samples. PCR primers in the opposite direction of sequencing primers were biotin-labelled (table 1). Primer specificities were tested in silico by BiSearch software (http://bisearch.enzim.hu). Primers' target regions were designed to cover all methylation sites that play role in gene regulation. In case of IGF2, after in silico testing primers targeting CpG sites in promoter region did not turn out to be specific. To avoid bias in analysis, specific primers targeting other CpG regions of IGF2 were used. BS-PCR reactions were performed using AmpliTaq 
Ács et al.: Methylation Status of CYP27B1 and IGF2 Correlate to BMI SDS in Children with Obesity

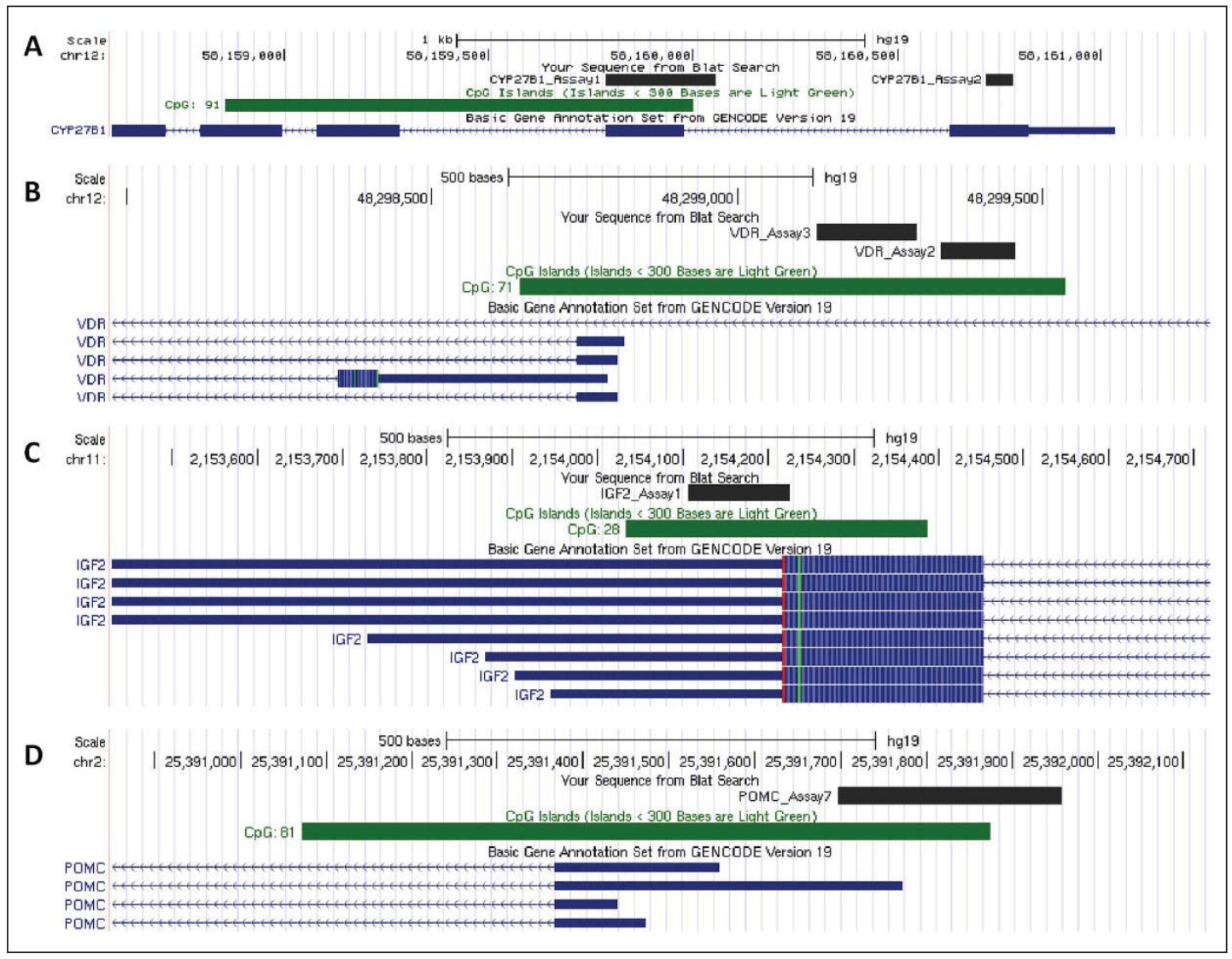

Fig. 1. Genes' loci and locations of bi-sulfite sequenced target regions. Investigated genes (labeled with lighter blue). CpG islands (location labeled with dark green) and bi-sulfite sequenced target regions (labeled with dark blue) presented with UCSC Genome Browser. (https://genome.ucsc.edu). A CYP27B1 B VDR C IGF2 D $P O M C$. chr = Chromosome; Assay = bisulfite sequenced target region; $C Y P 27 B 1=1$-alfa-hydroxylase gene; $V D R=$ vitamin D receptor gene, $I G F 2$ = insulin-like growth factor gene; $D=$ proopiomelanocortine gene.

Gold 360 Master Mix (Life Technologies, Carlsbad, CA, USA), LightCycler ${ }^{\circledR} 480$ ResoLight Dye (Roche Applied Science, Basel, Switzerland), primers at $0.2 \mu \mathrm{mol} / \mathrm{l}$ final concentrations, and bcDNA samples (20-40 ng bcDNA/reaction) in $15 \mu \mathrm{l}$ final volume. The final concentration of $\mathrm{MgCl}_{2}$ was $2.5 \mathrm{mmol} / \mathrm{l}$ except for the VDR and $P O M C$, where it was $1.5 \mathrm{mmol} / \mathrm{l}$. Real-time PCR amplification was carried out with the following thermocycling conditions on the LightCycler 480 system: $95^{\circ} \mathrm{C}$ for $10 \mathrm{~min}, 95^{\circ} \mathrm{C}$ for $30 \mathrm{~s}, 60^{\circ} \mathrm{C}$ with $0.4{ }^{\circ} \mathrm{C}$ decrease/ cycle for $30 \mathrm{~s}, 72^{\circ} \mathrm{C}$ for $30 \mathrm{~s}$ for 10 touchdown cycles, followed by amplification at $95^{\circ} \mathrm{C}$ for $30 \mathrm{~s}, 56^{\circ} \mathrm{C}$ for 30 $\mathrm{s}$, and $72{ }^{\circ} \mathrm{C}$ for $30 \mathrm{~s}$ in 50 cycles. Following completion of the PCR thermal cycling, high resolution melting (HRM) analysis began with denaturation at $95^{\circ} \mathrm{C}$ for $1 \mathrm{~min}$, cool down to $40^{\circ} \mathrm{C}$, and hold for $1 \mathrm{~min}$, then continuous warm up to $95^{\circ} \mathrm{C}$ with 20 acquisition $/{ }^{\circ} \mathrm{C}$ rate during melting curve fluorescence acquisition. $\mathrm{Cp}$ values and normalized melting curves were retrieved after data preprocessing using the LightCycler 480 software release 1.5.0 (Roche Applied Science). MS-HRM curve data were retrieved with the LightCycler ${ }^{\circledR}$ Gene Scanning software (Roche Applied Science).

In order to calibrate our MS-HRM assays, artificially methylated DNA samples were mixed with nonmethylated standard samples after bisulfite conversion resulting in different DNA methylation ratios $(0 \%$, $10 \%, 25 \%, 50 \%, 75 \%, 100 \%$ ) and analyzed by MS-HRM. The average methylation level of all blood samples was estimated by two experts independently by visually comparing melting peak curves with those of standard samples. In the course of data processing the four parallel methylation values were verified, outliner values were excluded. 
Ács et al.: Methylation Status of CYP27B1 and IGF2 Correlate to BMI SDS in Children with Obesity

Table 1. Target genes, assays and forward, biotinylated reverse primers for bisulfite-specific PCR and sequencing primers for pyrosequencing

\begin{tabular}{|c|c|c|c|}
\hline $\begin{array}{l}\text { Target gene } \\
\text { and assay }\end{array}$ & Forward primer & Reverse primer (biotinylated) & Sequencing primer \\
\hline $\begin{array}{l}\text { CYP27B1 } \\
\text { Assay } 1\end{array}$ & GGTTTTTGGGGGTAGAGAAGAT & СТСССТАТТСССАААСССААТСАА & GGGGGTAGAGAAGATTTA \\
\hline $\begin{array}{l}\text { CYP27B1 } \\
\text { Assay } 2\end{array}$ & AGAGGGGTTTGGGATGTT & ААСССТСАААТАССССТССААААТАТТССАТ & GGGATGTTTGTTAAGTT \\
\hline $\begin{array}{l}V D R \\
\text { Assay } 2\end{array}$ & GGATTAGGGATTAGGGAAGTTGAGATTTA & 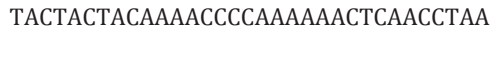 & AGATTTAGTTTTTTTGGGTGA \\
\hline $\begin{array}{l}V D R \\
\text { Assay } 3\end{array}$ & ATTTTAATTTGTGGGATTAGGTTGAGT & TAАТССААААТАСААССССССАСССТТССТАС & TGGAGTTTTGTAGTAGTAATAGG \\
\hline $\begin{array}{l}I G F 2 \\
\text { Assay1 }\end{array}$ & GGGATTGGGTTAGGAGAAGT & СССССССАААААТААССААСААТ & GGGTTAGGAGAAGTTTTA \\
\hline $\begin{array}{l}\text { POMC } \\
\text { Assay } 7\end{array}$ & GTTGGAAAGGGGTTGGAATTAGTA & ACAСССАСААААССАСТССТААСТТСТАС & TTTAGGAAGAATTTAATTATGGAT \\
\hline
\end{tabular}

$C Y P 27 B 1$ = 1-alfa-hydroxylase gene, $V D R=$ vitamin D receptor gene; $I G F 2$ = insulin-like growth factor gene; $P O M C=$ proopiomelanocortin gene.

PyroMark Q24 Sequencing

Providing single-base resolution information about the methylation state of a CpG island, we used direct sequencing. After bisulfite treatment and BS-PCR, all cytosines are converted to thymines except for those originally methylated. Qiagen PyroMark System (Qiagen Inc.) pyrosequencing technology was applied to analyze DNA methylation of BS-PCR. The read length that can be analyzed with the then available PyroMark chemistry was limited to 100 bp. Pyrosequencing was performed on a PyroMark Q24 instrument (Qiagen Inc.) using PyroMark Gold Q24 Reagents (Qiagen Inc.) according to the manufacturer's recommendations. Purification and subsequent processing of the biotinylated single-stranded DNA were performed in a run by applying (Qiagen Inc.) specific sequencing primers designed by PyroMark Assay Design software, SW 2.0 (Qiagen Inc.) in order to cover $\mathrm{CpG}$ sites in the amplicons. Sequencing results were analyzed using the PyroMark Q24 software v2.0.6 (Qiagen Inc.). To define DNA methylation status the average methylation percentage of a gene region was estimated by pyrosequencing.

\section{Statistical Analysis}

We used paired Student's t test, Pearson correlation analysis, and linear regression models to investigate the connection between the DNA methylation status, vitamin D levels and the metabolic parameters. Statistical analysis was performed by GraphPad Prism 6 (2015 GraphPad Software, Inc., La Jolla, CA, USA) and SPSS Version 20.0 ( 2011 IMB Corporation, Armonk, NY, USA).

\section{Results}

While analyzing data one proband showed extreme weight (159.2 kg) and BMI SDS (16.38) values. To avoid data distortion, the patient was considered as outlier and got excluded from further examination.

At the time of inclusion, 33 of 42 girls and 27 of 40 boys were in puberty, the average age of the two genders was close (girls: $12.52 \pm 3.10$ years, boys: $12.94 \pm 2.69$ years). After comparing anthropometric and metabolic status of girls and boys, we found that according to BMI SDS girls tend to be more obese than boys ( $4.51 \pm 0.29$ vs. $3.96 \pm 0.24 ; p=0.1571)$, the mother's weight gain during pregnancy was more pronounced in boys' than in girls' (13.67 \pm 2.51 vs. $11.94 \pm 1.47 ; p=0.5488)$, and glutamate pyruvate transaminase (GPT) $(28.10 \pm 3.813$ vs.18.23 $\pm 1.335, \mathrm{p}=0.0228)$ and alkaline phosphatase (ALP) $(230.3 \pm 16.41$ vs. $184.2 \pm$ $15.589 ; \mathrm{p}=0.0452$ ) levels were significantly lower in girls than in boys (supplementary table 1, available at http://content.karger.com/ProdukteDB/produkte.asp?doi=477462). 

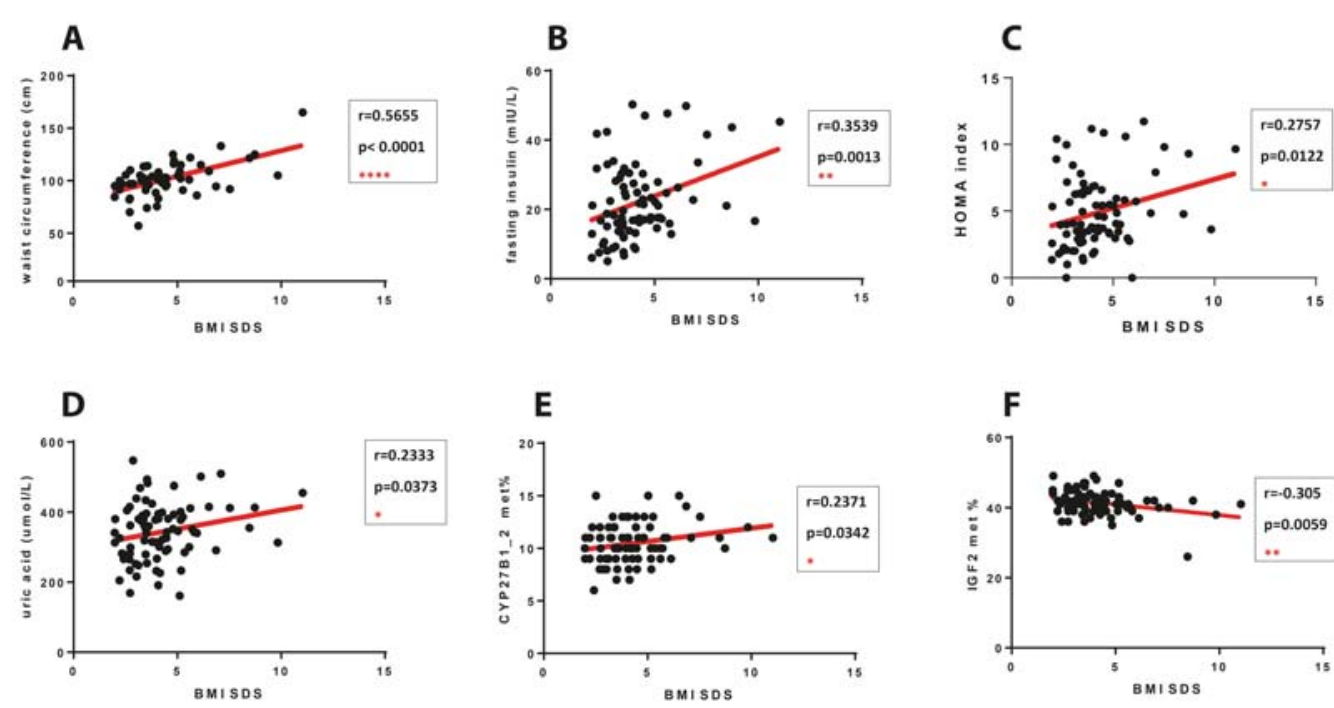

Fig. 2. Significant correlations of BMI SDS and anthropometric, metabolic parameters and methylation status. Significant positive correlations between BMI SDS and waist circumference $(\mathbf{A})(r=0.5655, p<0.0001)$, fasting insulin level (B) $(r=0.3539, p=0.0013)$, HOMA index (C) $(r=0.2757, p=0.0122)$, uric acid levels (D) $(\mathrm{r}=0.2333, \mathrm{p}=0.0373)$, CYP27B1 methylation status $(\mathbf{E})(\mathrm{r}=0.2371, \mathrm{p}=0.0342)$. Assessment IGF2 methylation status and BMI SDS (F) showed significant negative correlation ( $r=-0.305, p=0.0059)$. BMI SDS = BMI standard deviation score, HOMA: Homeostasis model; $C Y P 27 B 1$ = 1-alfa-hydroxylase gene; $I G F 2$ = insulin-like growth factor gene.

27 of 82 children with obesity had either hypertension (according to 24-hour blood pressure monitoring), carbohydrate metabolism disorder (according to oral glucose tolerance test - impaired glucose tolerance), and/or dyslipidemia (elevated cholesterol level). One patient had all three of the above mentioned comorbidities mentioned above and also presented elevated uric acid level. According to our results, hypertension and dyslipidemia individually was present in $18.29-18.29 \%$ and carbohydrate metabolism disorder was present in $13.41 \%$ of the cases. Nine of the 55 patients without hypertension, impaired glucose tolerance, and dyslipidemia presented isolated hyperuricemia (data not shown). 46 patients did not present any signs of comorbidities (supplementary fig. 1, available at $h t t p: / /$ content.karger.com/ProdukteDB/produkte.asp?doi=477462).

There was no significant correlation between the 25-0H vitamin D levels and metabolic parameters and DNA methylation status. There was a tendency of positive correlation of VDR methylation status and vitamin D levels (supplementary table 2, available at $h t t p: / /$ content. karger.com/ProdukteDB/produkte.asp?doi=477462).

Significant positive correlations between BMI SDS and waist circumference $(r=0.5655$, $p<0.0001)$, fasting insulin level $(r=0.3539, p=0.0013)$, Homeostasis Model Assessment (HOMA) index ( $\mathrm{r}=0.2757, \mathrm{p}=0.0122)$, uric acid levels $(\mathrm{r}=0.2333, \mathrm{p}=0.0373$ ) as well as CYP27B1 methylation status $(\mathrm{r}=0.2371, \mathrm{p}=0.0342)$ were found. IGF2 methylation status and BMI SDS showed significant negative correlation $(r=-0.305, p=0.0059)$. While performing statistical analysis, excluding these potential outliers did not modify the significance of the found correlations (supplementary table 3, available at http://content.karger.com/ ProdukteDB/produkte.asp?doi=477462) (fig. 2.) 
To further analyze the possible effects of DNA methylation status of CYP27B1 and IGF2 genes and $250 \mathrm{H}$ vitamin D on the BMI SDS, linear regression was performed. Because it is already known that IGF2 is associated with growth and body composition, vitamin D can be associated with higher BMI, and CYP27B1 converts $250 \mathrm{H}$ vitamin D to the active form $1,25(\mathrm{OH}) 2$ vitamin $\mathrm{D}$, we included these variables into our analyses. We entered variables stepwise with the linear regression function of SPSS. If a variable did not improve model fit, it was excluded from the model (backward elimination).

Model 1 included CYP27B1, IGF2 methylation status, and vitamin D level as variables. CYP27B1 and IGF2 methylation status were significantly associated with BMI SDS while vitamin D level did not show significant association (supplementary table 4, available at http://content.karger.com/ProdukteDB/produkte.asp?doi=477462). Vitamin D did not improve model fit; therefore, it was excluded from the final model (adjusted $\mathrm{R}^{2}=0.96 \mathrm{vs}$. 0.98). Model 2 accounted for $9.8 \%$ of the variance and was statistically significant $(F(2,78)=$ $5.246 \mathrm{p}=0.007$ ) (supplementary table 5, available at $h t t p: / /$ content.karger.com/ProdukteDB/ produkte. asp?doi=477462).

\section{Discussion}

The prevalence of obesity among children has been rising enormously over the past decades [20]. Children suffering from obesity tend to have higher risk for several obesityrelated problems such as high blood pressure, dyslipidemia, and type 2 diabetes mellitus during adolescence and later on during adulthood $[21,22]$. They are also more likely to remain obese as adults $[23,24]$. Several studies have suggested that imprinting and methylation can play role in weight control and obesity [25-28]. According to our results, there were significant positive correlations between BMI SDS and waist circumference, fasting insulin or glucose levels, HOMA index, uric acid level as well as higher blood pressure. $18.29 \%$ of our patients had either hypertension or impaired carbohydrate metabolism, while dyslipidemia was present in $13.41 \%$ and hyperuricemia in $10.97 \%$ of the cases. Altogether, $43.9 \%$ of these children with obesity already presented at least one of the main metabolic and cardiovascular risks of obesity. Our findings support the hypothesis that with early onset obesity the metabolic consequences of this condition start getting in action very early on in life [1].

Recent studies observed that increased BMI is associated with low circulating $250 \mathrm{H}$ vitamin D levels, but no evidence was proven for elevated $250 \mathrm{H}$ vitamin D lowering either weight or BMI [29]. Increased VDR function is associated with increased body fat and unfavorable lipid profile in mice [30]. Interestingly, our results did not show any significant correlations between $250 \mathrm{H}$ vitamin D and BMI SDS, metabolic status-describing parameters, blood pressure increase or VDR methylation status. Therefore, we could not confirm the association between lower vitamin D levels and unfavorable metabolic profiles [31]. However, the increased methylation of the gene of the $250 \mathrm{H}$ vitamin D activating CYP27B1 enzyme was associated with higher BMI SDS. Lower CYP27B1 expression in subcutaneous adipose tissue in adults with obesity was found by Wamberg etal. [10]. These findings indicate that $1,25(\mathrm{OH}) 2$ vitamin $\mathrm{D}$, the active form of vitamin $\mathrm{D}$, might be reduced in individuals with obesity - in adults and in children as well.

IGF2 is an important regulator of growth, obesity, and body composition. In young adults, IGF2 hypermethylation was associated with greater subcutaneous adiposity, but not with BMI, weight, height, waist circumference or visceral adiposity [6]. According to Chen et al. [32], in women suffering from obesity IGF2 methylation level was lowest in subcutaneous adipose tissue when compared with that in visceral adipose tissue or muscle. While studying Mexican-American lean and obese children Hernandez-Valerio et al. [33] found that children 
with lower IGF2/H19 methylation had higher birth weights than did children with higher methylation. Heijmans et al. [34] stated a negative association between $H 19$ methylation and body size. Supporting this, our data also show significant negative correlation between IGF2 methylation and increased BMI SDS. Therefore, we suggest that the lower IGF2 and H19 methylation status tend to have an impact not only on birth weight but later in childhood on the level of obesity described by BMI SDS.

According to our results, the methylation status of the POMC gene, which encodes an anorexogenic neuropeptide and plays key role in body weight regulation within the hypothalamus, did not show any correlations with BMI SDS. This might be due to the fact that CpG islands within one gene can be differently methylated and the primer used in our study targeted the gene's exon 1 region, while Kuehnen et al. [7] found association with childhood obesity and the hypermethylation of the intron 2 and exon 3 boundary region of $P O M C$ gene.

To analyze the possible effects of DNA methylation status of CYP27B1 and IGF2 genes and $250 \mathrm{H}$ vitamin D on BMI SDS we preformed linear regression. CYP27B1 and IGF2 methylation status were significantly associated with BMI SDS, while vitamin D level did not show any significant association, which suggests that hypomethylation of IGF2 and the hypermethylation of CYP27B1 might positively influence the rate of BMI observed in children with obesity. This can be explained by the fact that hypomethylation of the IGF2 gene might lead to increased expression of IGF2, which is responsible for growth and somatic development, and is associated with increased visceral fat mass [6]. Higher DNA methylation of the CYP27B1 gene can lead to decreased enzyme activity and lower levels of active 1,25(OH)2 vitamin D. According to experimental studies, $1,25(\mathrm{OH}) 2$ vitamin $\mathrm{D}$ has an active role in adipose tissue by modulating inflammation, adipogenesis, and adipocyte secretion [29]. We speculate that potential lower active vitamin D and increased IGF2 levels alter adipose tissue function and metabolism towards the direction of increasing BMI SDS.

To our knowledge, this is first study examining the methylation status of genes related to vitamin D metabolism related (CYP27B1 and VDR) and to metabolic status (IGF2 and POMC) in children with obesity. Although our research has reached its aims, there were some unavoidable limitations. First, because genomic DNA was extracted from peripheral whole blood includig many different cell types, we cannot provide correction for cell composition. Since DNA methylation is tissue-specific, adipocytes might show different methylation patterns than blood cells. Second, considering the epigenetic contribution to the pathogenesis of obesity, besides DNA methylation, other epigenetic pathways could influence the level of obesity. Therefore, further epigenetic researches are needed on this topic. Third, due to our relative small sample size and the seasonal and ethnic variation in vitamin D levels, conformation of our results by further investigations on larger populations are needed.

\section{Acknowledgments}

The authors thank Prof. Dr. Ilona Kovalszky, Dr. Kornélia Baghy, Dr. Attila Patócs for their advice and counsel and Krisztina Egedi, Mária Valuca Krauszné, Dr. Gábor Nyírő, Dr. Szilvia Hegedűs, Dr. Klára Horváth for the technical and statistical assistance. We thank our patients and their families for their willingness to participate in our research. All authors reviewed the paper and have approved the final article. This work was supported by the School of Ph.D. studies, Semmelweis University, Budapest, Hungary.

\section{Author Contribution Statement}

All authors contributed equally to this work. D.T., A.Sz. and O.D.Á. designed the study; O.D.Á., B.P. and P.H. performed experiments; A.L., D.T. and O.D.Á. collected and analyzed data; O.D.Á. and D.T. wrote the manuscript; P.H., B.P., D.T. and A.Sz. gave technical support and conceptual advice. 
Ács et al.: Methylation Status of CYP27B1 and IGF2 Correlate to BMI SDS in Children with Obesity

\section{Disclosure Statement}

The authors declare no conflict of interest.

\section{References}

1 Choudhury M, Friedman JE: Obesity: childhood obesity-methylate now, pay later? Nat Rev Endocrinol 2011; 7:439-440.

2 Kelly T, Yang W, Chen CS, Reynolds K, He J: Global burden of obesity in 2005 and projections to 2030. Int J Obes (London) 2008;32:1431-1437.

3 Herrera BM, Keildson S, Lindgren CM: Genetics and epigenetics of obesity. Maturitas 2011;69:41-49.

4 Drummond EM, Gibney ER: Epigenetic regulation in obesity. Current Opinion in Clin Nutr Metab Care 2013; 16:392-397.

5 Junien C, Nathanielsz P: Report on the IASO Stock Conference 2006:early and lifelong environmental epigenomic programming of metabolic syndrome, obesity and type II diabetes. Obes Rev 2007;8:487-502.

6 Huang RC, Galati JC, Burrows S, Beilin LJ, Li X, Pennell CE, van Eekelen J, Mori TA, Adams LA, Craig JM: DNA methylation of the IGF2/H19 imprinting control region and adiposity distribution in young adults. Clin Epigenet 2012;4:21.

7 Kuehnen P, Mischke M, Wiegand S, Sers C, Horsthemke B, Lau S, Keil T, Lee YA, Grueters A, Krude H: An Alu element-associated hypermethylation variant of the POMC gene is associated with childhood obesity. PLoS Genet 2012;8:e1002543.

8 Marco A, Kisliouk T, Weller A, Meiri N: High fat diet induces hypermethylation of the hypothalamic Pomc promoter and obesity in post-weaning rats. Psychoneuroendocrinology 2013;38;2844-2853.

9 Holick MF: The vitamin D epidemic and its health consequences. J Nutr 2005;135:2739s-2748s.

10 Wamberg L, Christiansen T, Paulsen SK, Fisker S, Rask P, Rejnmark L, Richelsen B, Pedersen SB: Expression of vitamin D-metabolizing enzymes in human adipose tissue - the effect of obesity and diet-induced weight loss. International J Obes (London) 2013;37:651-657.

11 Haussler MR, Jurutka PW, Mizwicki M, Norman AW: Vitamin D receptor (VDR)-mediated actions of 1alpha, 25(OH)(2)vitamin D(3): genomic and non-genomic mechanisms. Best Pract Res Clin Endocrinol Metab $201125543-559$.

12 Fetahu IS, Hobaus J, Kallay E:. Vitamin D and the epigenome. Front Physiol 2014;5:164.

13 Parikh SJ, Edelman M, Uwaifo GI, Freedman RJ, Semega-Janneh M, Reynolds J, Yanovski JA: The relationship between obesity and serum 1,25-dihydroxy vitamin D concentrations in healthy adults. J Clin Endocrinol Metab 2004:89:1196-1199.

14 Carlin AM, Rao DS, Meslemani AM, Genaw JA, Parikh NJ, Levy S, Bhan A, Talpos GB: Prevalence of vitamin D depletion among morbidly obese patients seeking gastric bypass surgery. Surg Obes Related Dis 2006;2: 98-103; discussion 104

15 Snijder MB, van Dam RM, Visser M, Deeg DJ, Dekker JM, Bouter LM, Seidell JC, Lips P: Adiposity in relation to vitamin D status and parathyroid hormone levels: a population-based study in older men and women. J Clin Endocrinol Metab 2005;90:4119-4123.

16 Vilarrasa N, Maravall J, Estepa A, Sanchez R, Masdevall C, Navarro MA, Alia P, Soler J, Gomez JM: Low 25-hydroxyvitamin D concentrations in obese women: their clinical significance and relationship with anthropometric and body composition variables. J Endocrinol Invest 2007;30:653-658.

17 Stein EM, Strain G, Sinha N, Ortiz D, Pomp A, Dakin G, McMahon DJ, Bockman R, Silverberg SJ: Vitamin D insufficiency prior to bariatric surgery: risk factors and a pilot treatment study. Clin Endocrinol (Oxf) 2009;71: 176-183.

18 Jorde R, Grimnes G: Vitamin D and metabolic health with special reference to the effect of vitamin D on serum lipids. Prog Lipid Res 2011;50:303-312.

19 Hobaus J, Hummel DM, Thiem U, Fetahu IS, Aggarwal A, Mullauer L, Heller G, Egger G, Mesteri I, BaumgartnerParzer S, Kallay E: Increased copy-number and not DNA hypomethylation causes overexpression of the candidate proto-oncogene CYP24A1 in colorectal cancer. Int J Cancer 2013;133:1380-1388.

20 Wijnhoven TM, van Raaij JM, Spinelli A, Rito AI, Hovengen R, Kunesova M, Starc G, Rutter H, Sjoberg A, Petrauskiene A, O'Dwyer U, Petrova S, Farrugia Sant'angelo V, Wauters M, Yngve A, Rubana IM, Breda J: WHO European Childhood Obesity Surveillance Initiative 2008: weight, height and body mass index in 6-9-year-old children. Pediatr Obes 2013;8:79-97.

21 Freedman DS, Khan LK, Dietz WH, Srinivasan SR, Berenson GS: Relationship of childhood obesity to coronary heart disease risk factors in adulthood: the Bogalusa Heart Study. Pediatrics 2001;108:712-718.

22 Freedman DS, Dietz WH, Srinivasan SR, Berenson GS: Risk factors and adult body mass index among overweight children: the Bogalusa Heart Study. Pediatrics 2009:123:750-757.

23 Serdula MK, Ivery D, Coates RJ, Freedman DS, Williamson DF, Byers T: Do obese children become obese adults? A review of the literature. Prevent Med 1993;22:167-177. 
Ács et al.: Methylation Status of CYP27B1 and IGF2 Correlate to BMI SDS in Children with Obesity

24 Whitaker RC, Wright JA, Pepe MS, Seidel KD, Dietz WH: Predicting obesity in young adulthood from childhood and parental obesity. N Engl J Med 1997;337:869-873.

25 Pinnick KE, Karpe F: DNA methylation of genes in adipose tissue. Proc Nutr Soc 2011;70:57-63.

26 Campión J, Milagro F, Martinez JA: Epigenetics and obesity. Prog Mol Biol Transl Sci 201094 291-347.

27 Lavebratt C, Almgren M, Ekstrom TJ: Epigenetic regulation in obesity. Int J Obes (Lond) 2012;36:757-765.

28 Lillycrop KA, Burdge GC: Epigenetic changes in early life and future risk of obesity. Int J Obes (Lond) 2011;35: 72-83.

29 Mutt SJ, Hypponen E, Saarnio J, Jarvelin MR, Herzig KH: Vitamin D and adipose tissue-more than storage. Front in Physiol 2014;5:228.

30 Wong KE, Szeto FL, Zhang W, Ye H, Kong J, Zhang Z, Sun XJ, Li YC: Involvement of the vitamin D receptor in energy metabolism: regulation of uncoupling proteins. Am J Physiol Endocrinol Metab 2009;296:E820-828.

31 Hutchinson MS, Figenschau Y, Almas B, Njolstad I, Jorde R: Serum 25-hydroxyvitamin D levels in subjects with reduced glucose tolerance and type 2 diabetes - the Tromso OGTT-study. Int J Vitam Nutr Res 2011;81:317327.

32 Chen M, Macpherson A, Owens J, Wittert G, Heilbronn LK: Obesity alone or with type 2 diabetes is associated with tissue specific alterations in DNA methylation and gene expression of PPARGC1A and IGF2. J Diabetes Res Clin Metab 2012; DOI: http://dx.doi.org/10.7243/2050-0866-1-16.

33 Hernandez-Valero MA, Rother J, Gorlov I, Frazier M, Gorlova O: Interplay between polymorphisms and methylation in the H19/IGF2 gene region may contribute to obesity in Mexican-American children. J Dev Orig Health Dis 2013;4:499-506.

34 Heijmans BT, Kremer D, Tobi EW, Boomsma DI, Slagboom PE: Heritable rather than age-related environmental and stochastic factors dominate variation in DNA methylation of the human IGF2/H19 locus. Hum Mol Genet 2007;16:547-554. 